\section{Combining dendrochronology and radiocarbon dating at the Late Medieval site of Sant'Alvise, Venice, Italy}

\author{
Nicoletta Martinelli, ${ }^{1}$ John Meadows, ${ }^{2}$ \\ Erio Valzolgher, ${ }^{3}$ Olivia Pignatelli, ${ }^{1}$ \\ Laura Anglani, ${ }^{4}$ Bernd Kromer ${ }^{5}$ \\ ${ }^{1}$ Dendrodata s.a.s., Verona, Italy; \\ 'Zentrum für Baltische und \\ Skandinavische Archäologie, Schleswig, \\ Germany; ${ }^{3}$ Ricerche Archeologiche \\ s.n.c./Archäologische Untersuchungen \\ O.H.G., Bressanone-Brixen (BZ); \\ ${ }^{4}$ Soprintendenza per i Beni Archeologici \\ per il Veneto, Nucleo Archeologia Umida \\ Subacquea Italia Centro Alto Adriatico - \\ NAUSICAA, Scientific Division, Venice, \\ Italy; ${ }^{5}$ Heidelberger Akademie der \\ Wissenschaften, Institut für \\ Umweltphysik, Universität Heidelberg, \\ Germany
}

\section{Abstract}

The excavation of a series of wooden structures, built to reclaim land on Venice's northwestern edge, provided an opportunity, using Bayesian chronological modeling, to combine precise dendrochronological and radiocarbon dating results with floating tree-ring chronologies, artifactual dating and stratigraphic evidence. Our model indicates that the first structure was built in the early AD 1340 s, the second in the early $\mathrm{AD} 1370$ s, and the reclaimed area was extended again within about a decade of cal AD 1400. The dates of these building episodes bracket the deposition of important pottery assemblages, including imports from Spain and the Eastern Mediterranean.

\section{Introduction}

Excavations in 1996-1997 by the Soprintendenza per i Beni Archeologici per il Veneto - NAUSICAA at Sant'Alvise di Cannaregio - Area ex-CIGA, at the northwestern edge of Venice - in an area traditionally used for horticulture and craft activities identified several wooden structures, built to reclaim land from the lagoon (Fozzati, 1997).

Land reclamation at Sant'Alvise can be placed in the context of Late Medieval developments in Venice. The northern edge of the city displays a markedly ragged outline in the map drawn by Paolino da Venezia (also known as
Paolino Minorita) (Figure 1) in the early $14^{\text {th }}$ century AD (certainly prior to AD 1325-1329) (Concina, 2003), resulting from both public works and gratiae de atterar (permissions for land expansion) conceded to private individuals (Concina, 2000, 2003). Land reclamations at Sant'Alvise, following usual practice in Venice, consist of deliberate backfills within wooden caissons, followed by natural sedimentation. Backfill comprised spoil from canal excavation, waste from local workshops, and rubble from demolished buildings (Bortoletto, 2005), which was deposited soon after the construction of the wooden structures.

Stratigraphically, the earliest were Structures Y and X. Structure Y was sunk into a sterile deposit, whilst the later Structure $\mathrm{X}$ was set immediately behind Structure Y, at a higher level. After a phase of natural sedimentation and the deliberate deposition of a rubble layer exposed to tidal action, a third complex was built which comprises Structures A, B, and STAT (Figure 2).

The dating programme at Sant'Alvise aimed to date the phases of land reclamation, and thus the artifactual assemblages from the backfill; to extend dendrochronological data coverage for larch, spruce and fir; to use crossmatching of short tree-ring sequences to interpret radiocarbon results for oak; and to validate the use of Bayesian chronological modeling when scientific dating results are precise and tightly constrained.

\section{Dendrochronology}

Timbers were selected for dendrochronological analysis according to whether the species is suitable for dendrochronology, whether local or regional reference chronologies exist, the number of tree rings present, and the presence of bark-edge or sapwood, to obtain a representative number of timbers from each structure. As the wood was partially waterlogged, sampling was performed by cutting transverse sections.

In all, 160 samples were collected, comprising European larch (Larix decidua Mill.), Norway spruce (Picea abies [L.] Karst.), silver fir (Abies alba Mill.), and deciduous oak (Quercus sp. sectio ROBUR) [identified following Cambini (1967) and Schweingruber (1990)]. Standard dendrochronological methods were followed (Fritts, 1976; Baillie, 1982). Tree rings were measured from pith to barkedge using the LINTAB device (F. Rinn, Heidelberg, Germany), to a precision of 0.01 $\mathrm{mm}$. Data were recorded and processed using the software TSAP $^{\odot}$ (Rinn, 2003) and CATRAS $^{\odot}$ (Aniol, 1983).

Visual and statistical synchronisations facilitated the construction of mean chronologies
Correspondence: Nicoletta Martinelli, Dendrodata s.a.s., via Cesiolo 18, 37121 Verona, Italy.

Tel./Fax: +39.045 .8013533$

E-mail: nicoletta.martinelli@dendrodata.it

Key words: Venice, Late Middle Ages, den drochronology, radiocarbon, Bayesian modelling.

Acknowledgments: the authors wish to gratefully acknowledge the Municipality of Venice for funding the dendrochronological and radiocarbon dating; Luigi Fozzati for granting the permit to carry out the sampling, and Flavio Cafiero for his assistance during fieldwork; the Soprintendenza per $i$ Beni Archeologici per il Veneto for granting permission to use unpublished data from the Sant'Alvise excavations; the Biblioteca Nazionale Marciana for authorising the reproduction of Paolino da Venezia's map of Venice; the colleagues of the Hohenheim Tree-Ring Laboratory and the Neuchâtel Cantonal Archaeological Museum Laboratory for providing unpublished data from the German and Swiss oak reference chronologies; and Piero Falchetta for providing helpful information about Venetian cartography.

Citation: Martinelli N, Meadows J, Valzolgher E, Pignatelli 0, Anglani A, Kromer B, 2014. Combining dendrochronology and radiocarbon dating at the Late Medieval site of Sant'Alvise, Venice, Italy. In: RH Tykot (ed.), Proceedings of the $38^{\text {th }}$ International Symposium on Archaeometry - May $10^{\text {th }}-14^{\text {th }} 2010$, Tampa, Florida. Open Journal of Archaeometry 2:5263.

Presented at the $38^{\text {th }}$ International Symposium on Archaeometry - May $10^{\text {th }}-14^{\text {th }} 2010$, Tampa, Florida.

This work is licensed under a Creative Commons Attribution 3.0 License (by-nc 3.0).

(C) Copyright N. Martinelli et al., 2014

Licensee PAGEPress, Italy

Open Journal of Archaeometry 2014; 2:5263

doi:10.4081/arc.2014.5263

for each species within each structure; crossmatching was then sought between mean chronologies and relevant reference chronologies (Table 1): i) the Italian-Slovenian larch chronology (AD 756-1997; Levanič et al., 2001), and the northeast Italian larch chronology (AD 781-1988) (Bebber, 1990; Bebber et al., 1992); ii) the Veneto regional spruce chronology ( $12^{\text {th }}-14^{\text {th }}$ centuries AD), comprising historical series from the provinces of Verona and Padua; iii) the western Veneto local fir chronology, from $12^{\text {th }}-14^{\text {th }}$ centuries $\mathrm{AD}$ buildings.

Fifty conifer planks, the majority of which contained more than 50 tree rings, were dated in Structures $\mathrm{Y}$ and X. None of these samples retained the bark-edge, so the last-ring dates are not the felling years of the trees concerned. 
Sapwood survival in some larch samples allows us to determine, using sapwood estimates for larch in the Italian Alps (Corona, 1984), a narrow date range within which the trees may have been felled. Sapwood cannot be recognised in fir and spruce, so the last-ring date represents a terminus ante quem non for a sample without bark-edge. The proximity of the bark-edge is recognizable in some samples: many planks are tangential slabs (sciaveri), with no evidence of woodworking on their convex external surface. In such cases, the absence of bark-edge indicates natural erosion of the external surface, and the tree was probably felled almost immediately after the last dated ring.

Structure Y, a low vertical plank structure, was dated by 26 planks of larch, fir and spruce. The proximity of bark-edge on 4 fir samples and the only larch sample, with last-ring dates between $\mathrm{AD} 1336$ and $\mathrm{AD}$ 1341, dates the treefelling to $\mathrm{AD} 1342$, or very soon afterwards. Structure X, immediately behind and against Structure Y, comprised a double row of posts reinforced by horizontal planks. A felling date range of $\mathrm{AD} 1369-1379$ was calculated for 11 larch planks, based on estimated numbers of missing sapwood rings. This range is consistent with the lack of woodworking traces in 1 spruce and 2 fir elements with last-ring dates of $\mathrm{AD} 1368$, which dates the felling of these 3 timbers to AD 1369 , or shortly thereafter.

Short floating chronologies were obtained from oak posts in the stratigraphically later Structures A and B (and oak timbers in the associated structures A1R, A2R and STAT). Although these could not be dated absolutely, due to the lack of an Italian Late Medieval oak reference chronology and the short length of most of the series, they were analysed to identify contemporaneous elements and to select samples for radiocarbon dating. The synchronisation of oak sequences of less than 30 years was performed by optical cross-matching, according to the method of Lambert and Orcel
(1977) and Billamboz (1989) for use in coherent archaeological contexts, which includes the recognition of characteristic years and sequences during the measurement process.

The bark-edge is preserved in 55 of the 67 synchronised oak posts, and Structures Y, A and $B$ each proved to contain timbers felled in a single year. Structure A, divided into groups $\mathrm{A} 1, \mathrm{~A} 2$ and $\mathrm{A} 3$, was built almost exclusively of posts from trees felled in 1 year; just 2 posts from A3 were felled the preceding year. The strong similarity among the series patterns suggests that some posts may be coppice or pollard shoots of the same tree. Dendrochronology could not confirm that the planks and posts in Structure A were of the same date, or that Structures A and B were contemporaneous, but it showed that 2 posts from Structure A1R were probably cut from the same tree as 1 joint in Structure A.

For Structure STAT, 2 oak mean chronologies were built, each of just 3 samples with more than 50 rings. Given the lack of an Italian oak chronology, an attempt was made to crossdate them against the chronologies for southcentral Germany (8480 BC-AD 2009; Becker et al., 1985; Friedrich et al., 2004; Friedrich M., personal communication) and Switzerland (AD 924-1985; Gassmann P., personal communication), which are nearest to our study area, but without success. It is worth noting that the remaining samples from Structure STAT, conifer and oak, remain respectively undated and not cross-matched, suggesting that these timbers came from multiple sources.

\section{Radiocarbon dating}

All samples were dated at the Heidelberg Radiocarbon Laboratory. The wood samples ( $n=11)$ were milled and pretreated using an acid-base-acid (ABA) sequence with $\mathrm{NaOH}$ overnight, $\mathrm{HCl}, \mathrm{NaOH}$ and $\mathrm{HCl}$ for $1 \mathrm{~h}$ each, all at $80^{\circ}$. The wood was combusted in a deVries type combustion system, and the $\mathrm{CO}_{2}$ was purified. The samples were measured for 9-12 days in low-level gas counters (Kromer and Münnich, 1992). The radiocarbon results reported in Table 2 are conventional radiocarbon ages (Stuiver and Polach, 1977).

\section{Bayesian modelling}

Bayesian chronological models (Buck et al., 1996) combine likelihoods, given by calibrated radiocarbon measurements and other independent scientific dating results, with priors, which are relative and absolute dating constraints (such as stratigraphic relationships), to produce mathematically robust posterior density estimates of dates of the samples themselves and of associated events. These estimates are reported in italics, to emphasise that they are derived from a model and are not independent of each other.

Bayesian models therefore depend on understanding the relative ages of dated samples. At Sant'Alvise, the samples' intrinsic ages are known, the radiocarbon results and dendrochronological felling date ranges are precise, and these likelihoods can be tightly constrained by stratigraphy, dendrochronological cross-matching, and a historically dated artifact. There are 2 potentially important unknowns: the time between tree-felling and construction, and whether any timber was reused. Available evidence suggests these factors are negligible, except for the possible presence of re-used timbers in Structure STAT. Crossmatching shows little if any variation in felling date between timbers of the same species within a single structure.

The accuracy of the model output also depends on the algorithm used to calibrate radiocarbon results to a specified resolution, and on how well radiocarbon calibration curves

Table 1. Cross-dating parameters between site mean chronologies and relevant reference chronologies.

\begin{tabular}{|c|c|c|c|c|c|c|}
\hline \multirow[t]{2}{*}{ Site mean curves } & \multirow{2}{*}{$\begin{array}{c}\text { Length of the series } \\
\text { (years) }\end{array}$} & \multirow[t]{2}{*}{ Reference chronologies } & \multicolumn{4}{|c|}{ Statistical parameters } \\
\hline & & & GLK $(\%)$ & TBP & TH & CDI \\
\hline \multirow[t]{2}{*}{ Larch outer planks Structure X } & \multirow[t]{2}{*}{219} & Italian-Slovenian larch chronology & 73 & 14.0 & 15.0 & 106 \\
\hline & & Northeast Italian larch chronology & 71 & 10.4 & 10.9 & 75 \\
\hline Larch inner planks Structure X & 178 & $\begin{array}{l}\text { Italian-Slovenian larch chronology } \\
\text { Northeast Italian larch chronology }\end{array}$ & $\begin{array}{l}74 \\
70\end{array}$ & $\begin{array}{l}10.7 \\
10.7\end{array}$ & $\begin{array}{l}10.7 \\
10.5\end{array}$ & $\begin{array}{l}79 \\
74\end{array}$ \\
\hline Fir inner planks Structure X & 122 & Western Veneto fir chronology & 64 & 5.6 & 5.6 & 36 \\
\hline Fir planks Structure Y & 85 & Western Veneto fir chronology & 69 & 4.5 & 5.2 & 33 \\
\hline Spruce inner planks Structure X & 159 & Veneto spruce chronology & 69 & 5.3 & 4.7 & 33 \\
\hline Spruce planks Structure Y & 143 & Veneto spruce chronology & 68 & 6.1 & 5.3 & 38 \\
\hline
\end{tabular}

GLK, Gleichläufigkeit; TBP, Baillie and Pilcher's T-value; TH, Hollstein's T-value; CDI, cross-date index. 
Table 2. Radiocarbon determinations of oak (Quercus sp. sectio ROBUR) structural timbers from Sant'Alvise. $\delta^{13} \mathrm{C}$ values are expressed with respect to Pee Dee Belemnite. The calibrated date ranges have been calculated by the maximum intercept method (Stuiver and Reimer, 1986), using the programme OxCal 4.1.7 and the IntCal09 data set (Reimer et al., 2009). The posterior density estimates are derived from the model shown in Figure 3 and are for the felling dates of the timbers concerned.

\begin{tabular}{|c|c|c|c|c|c|c|c|}
\hline $\begin{array}{l}\text { Laboratory } \\
\text { code }\end{array}$ & Structure & Timber & Dated rings & $\begin{array}{l}\delta^{13} \mathrm{C} \\
(\%)\end{array}$ & $\begin{array}{l}\text { Radiocarbon age } \\
\text { (BP) }\end{array}$ & $\begin{array}{l}\text { Calibrated date } \\
\text { ( } 95 \% \text { confidence) }\end{array}$ & $\begin{array}{l}\text { Posterior density estimate } \\
\text { (95\% probability) } \\
\text { for felling date }\end{array}$ \\
\hline Hd-20075 & Y & Post 5 & Outer 4 rings including bark-edge & -26.7 & $622 \pm 29$ & Cal AD 1280-1410 & Cal $A D$ 1341-6 \\
\hline Hd-19965 & $X$ & Post 28 & Outer 4 rings including bark-edge & -26.4 & $677 \pm 19$ & Cal AD 1275-1385 & $\mathrm{Cal} A D$ 1369-1373 \\
\hline Hd-19912 & $X$ & Post 14 & Outer 4 rings including bark-edge & -27.3 & $586 \pm 42$ & Cal AD 1290-1430 & $\mathrm{Cal} A D$ 1367-1371 \\
\hline Hd-20203 & STAT & Plank 22 & 32 rings (heartwood only) & -25.0 & $623 \pm 30$ & Cal AD 1280-1410 & After cal $A D$ 1317-1415 \\
\hline Hd-20207 & STAT & Plank 10 & 8 rings (7 sapwood, no bark-edge) & -26.7 & $707 \pm 21$ & Cal AD 1265-1295 & $\begin{array}{l}\text { Soon after cal } A D \text { 1271-1303 } \\
\text { (92\% probability) }\end{array}$ \\
\hline $\begin{array}{l}\text { Hd-20211 } \\
\text { Hd-20214 }\end{array}$ & $\begin{array}{l}\text { B } \\
\text { B }\end{array}$ & $\begin{array}{l}\text { Post } 4 \\
\text { Post } 7\end{array}$ & $\begin{array}{l}\text { Outer } 8 \text { rings including bark-edge } \\
\text { Outer } 5 \text { rings including bark-edge }\end{array}$ & $\begin{array}{l}-28.9 \\
-27.6\end{array}$ & $\begin{array}{l}585 \pm 25 \\
548 \pm 26\end{array}$ & $\begin{array}{l}\text { Cal AD 1300-1420 } \\
\text { Cal AD 1310-1440 }\end{array}$ & Cal AD 1392-1414 \\
\hline $\begin{array}{l}\text { Hd-20215 } \\
\text { Hd-19903 }\end{array}$ & $\begin{array}{l}\mathrm{A} 1 \\
\mathrm{~A} 2\end{array}$ & $\begin{array}{l}\text { Post } 18 \\
\text { Post } 7\end{array}$ & $\begin{array}{l}\text { Outer } 8 \text { rings including bark-edge } \\
\text { Outer } 7 \text { rings including bark-edge }\end{array}$ & $\begin{array}{l}-28.3 \\
-27.2\end{array}$ & $\begin{array}{l}592 \pm 20 \\
618 \pm 29\end{array}$ & $\begin{array}{l}\text { Cal AD 1300-1410 } \\
\text { Cal AD 1280-1410 }\end{array}$ & Cal AD 1388-1407 \\
\hline $\begin{array}{l}\text { Hd-20204 } \\
\text { Hd-20212 }\end{array}$ & $\begin{array}{l}\mathrm{A} 2 \mathrm{R} \\
\mathrm{A} 2 \mathrm{R}\end{array}$ & $\begin{array}{l}\text { Post } 25 \\
\text { Post } 15\end{array}$ & $\begin{array}{l}\text { Outer } 10 \text { rings including bark-edge } \\
\text { Outer } 4 \text { rings including bark-edge }\end{array}$ & $\begin{array}{l}-28.1 \\
-23.2\end{array}$ & $\begin{array}{l}627 \pm 22 \\
606 \pm 79\end{array}$ & $\begin{array}{l}\text { Cal AD 1285-1400 } \\
\text { Cal AD 1260-1450 }\end{array}$ & Cal AD 1379-1407 \\
\hline
\end{tabular}

characterise sub-decadal changes in atmospheric radiocarbon concentrations. We have used 0xCal 4.1.7 (Bronk Ramsey, 2009) with annual resolution, as the intrinsic and relative ages of samples are usually known to within 1 year. The programme's default resolution (5 years) gives fractionally broader posterior density estimates. The estimates reported here were obtained using the IntCal09 calibration curve (Reimer et al., 2009), which are marginally broader than those produced using IntCal98 (Stuiver et al., 1998).

The model (Figure 3) incorporates the overall stratigraphic sequence: Structure $\mathrm{Y}$ was built first, then Structure X, then Structures A and B. Structures A and B, which are linked by Structures A1R and A2R, were apparently built within a single programme. Structure STAT, a retaining wall behind Structure A, was probably assembled at the same time. These 3 phases of construction are separated in time by periods of sediment accumulation, after the initial rapid backfilling. A seal which could not have been struck before AD 1356 was deposited in the rubble backfilling Structure X, providing a terminus post quem for its completion. The model shows a good fit between this sequence and the felling dates $\left(\mathrm{A}_{\text {model }}>60 \%\right)$ (Bronk Ramsey, 2009).

The model incorporates dendrochronological dating by offsetting the date of the latest dated ring in Structures $\mathrm{X}$ and $\mathrm{Y}$ by a uniform probability distribution for the number of rings lost between the latest ring and the bark-edge. The model allows up to 3 missing outer rings for the 5 timbers from Structure $Y$ and the 3 timbers in Structure $X$ that were seen to be almost complete to the bark-edge. A second uniform probability distribution for Structure $\mathrm{X}$ is the felling date range of AD 1369-1379 calculated for 11 larch planks.
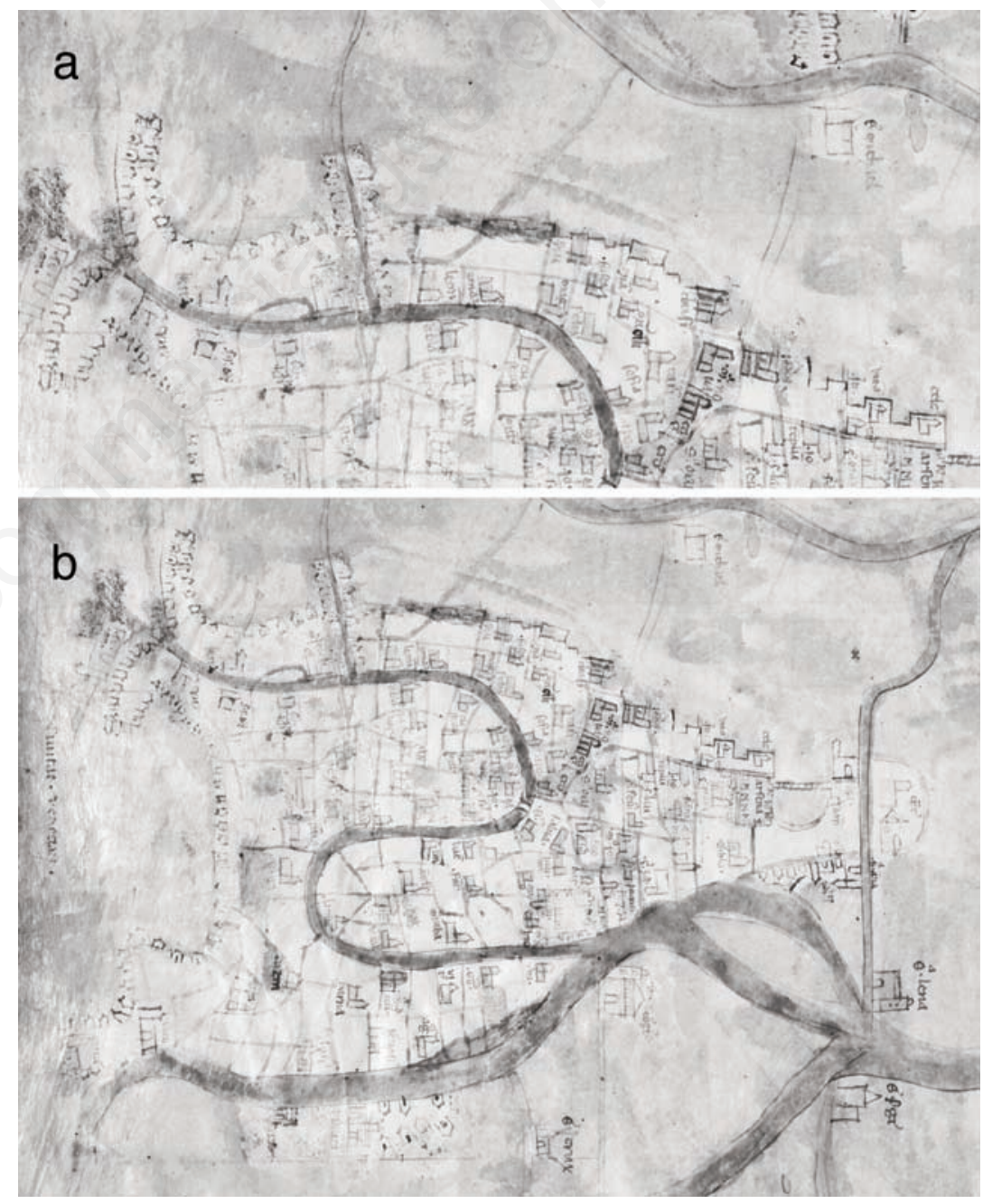

Figure 1. Map of Venice from the Chronologia Magna by Paolino da Venezia (b) (early $14^{\text {th }}$ century $\mathrm{AD}$ ), with enlarged detail of the northern edge of the city (a) (Biblioteca Nazionale Marciana, ms. Lat. Z. 399 [=1610], Chronologia Magna, f. 7r: Pianta di Venezia). Reproduced with permission of the Ministero per i Beni e le Attività Culturali, (C)Biblioteca Nazionale Marciana. All rights reserved (Rif. n. 4053 class. 28.13.15.02/4, 30 November 2010). 
Radiocarbon samples were taken from the outermost annual rings of 11 oak timbers, 9 of which were complete to the bark-edge (Table 2 ). The number of rings in each sample was recorded, and, taking the radiocarbon result as the date of the ring at the midpoint of the sample, we have shifted the calibrated date by the number of rings from the midpoint to the barkedge, to obtain a probability distribution for the felling date itself.

For Structure Y, the function Combine is used to estimate the construction date, which implies that the structure was built in a single year using only freshly felled timbers, and therefore that conifer planks are identical in date to oak Post 5. Satisfactory agreement $\left(A_{\text {comb }}=72.0 \% ; A_{n}=50.0 \% ; n=2\right)$ (Bronk Ramsey, $1995)$ indicates that this assumption is sustainable (Figure 3: build Structure $Y$, cal AD 1341-5, 95\% probability).

Posts 14 and 28 in Structure X may appear to contradict the interpretation that all timbers were freshly felled when used. The radiocarbon results are not statistically consistent (T'=3.9; T' $[5 \%]=3.8 ;=1$ ) (Ward and Wilson, 1978) and, as each sample consisted of the last 4 rings including the bark-edge, this suggests that these timbers were felled at slightly different times. The Post 14 dendrochronological sequence, in particular, is very short (20 rings), so a conclusive cross-match between Post 14 and any other sample is not possible, but the only matching position found suggests that Post 14 was felled 2 years before Post 28 . A radiocarbon wiggle-match (Bronk Ramsey et al., 2001) tests whether this cross-match fits the radiocarbon results (Figure 4). The felling date thus obtained for Post 28 fits perfectly with the dating of Structure X conifer planks
(Figure 3). In the model, we have assumed that Post 14 was indeed felled 2 years before Post 28.

The date of Structure $\mathrm{X}$ is tightly constrained by dendrochronology. The fir and spruce planks on the inner side of the structure (felled AD 1369, or shortly thereafter) cannot have been added before the posts were in place or after the structure was backfilled. A felling date range of AD 1369-1379 was calculated, based on sapwood survival, for the larch planks on both the inner and outer sides. Larch planks on the outer side cross-match strongly with those on the inner side, which must have been inserted at the same time as the fir and spruce planks. The model therefore assumes that all the conifers, and Post 28, have the same felling date. The results fit this interpretation $\left(A_{\text {comb }}=112.1 \% ; A_{n}=40.8 \% ; n=3\right)$, giving a construction date of $c a l A D$ 1368-72 (Figure 3: build Structure X, 95\% probability).

The model uses dendrochronological crossmatching, which demonstrated that the 2 radiocarbon-dated timbers within each of Structures A, A2R and B have the same felling date. The dated timbers from different structures do not cross-match, but the model assumes that these timbers were felled during a continuous phase of activity. It does not use the assembly sequence (Structure B could have been built before Structure A, but not vice versa) to constrain the felling dates, as this sequence may have lasted under a year, particularly as 2 posts in Structure A1R were probably from the same tree as a timber in Structure A. The model uses the Last function to estimate the latest felling date within this phase, and thus the probable end of construction (cal AD 1393-1414, 95\% probability).
Structure STAT supported Structure A, but its 2 radiocarbon samples do not cross-match each other. Plank 10 had 7 sapwood rings, included in the 8-year block dated by Hd-20207, but no bark-edge. A sapwood estimate for young oaks in this region is 5 -13 years, so Plank 10 may have lost only the bark-edge. It was probably felled in the late $13^{\text {th }}$ or very early $14^{\text {th }}$ century $\mathrm{AD}$, and must have been re-used in Structure STAT. In the model, the earliest possible felling date for Plank 10 (assuming the minimum number of missing sapwood rings) is used as a terminus post quem for the end of this building phase. Two other timbers, 1 with sapwood, cross-match with Plank 10 and were probably also re-used. Plank 22 had lost a number of heartwood rings, and at least 11 sapwood rings, an appropriate minimum for mature oaks in this region (Corona, 1970, 1974). The model estimates that Plank 10 was felled no earlier than cal AD 1270-1303 (Hd20207+5, 92\% probability), and Plank 22 not before cal AD 1317-1415 (Hd-20203+27, 95\% probability). Two other timbers (heartwoodonly) cross-match with Plank 22, and could have been freshly felled when Structure STAT was built.

When all the dating evidence is incorporated, none of the likelihoods is a misfit or outlier (indicated by the good index of agreement, $A>60$, for each likelihood in Figure 3), despite the rigid constraints of the model structure. Given the samples' clear functional associations with the structures, there should not be any misfits if the likelihoods and priors are accurate. While the precise dating of Structures $\mathrm{X}$ and $\mathrm{Y}$ depends on the dendrochronological dates for many timbers in each structure, the precision with which

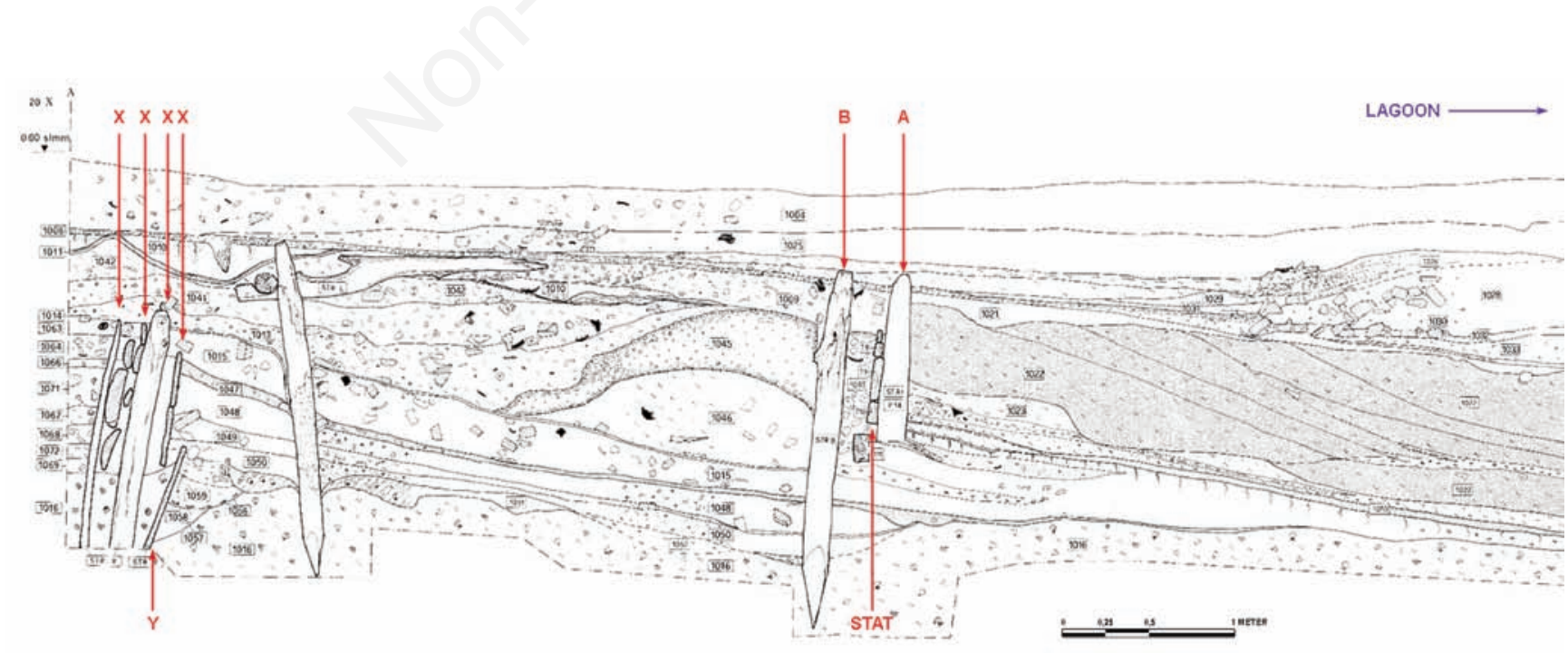

Figure 2. Sant'Alvise. Section of the excavated area, showing the sequence of land reclamation structures (Structures Y, X, B, A, and STAT) [modified after Fozzati (1997)]. Reproduced with permission of Comune di Venezia (Rif. n. 184396, 23 April 2010). 


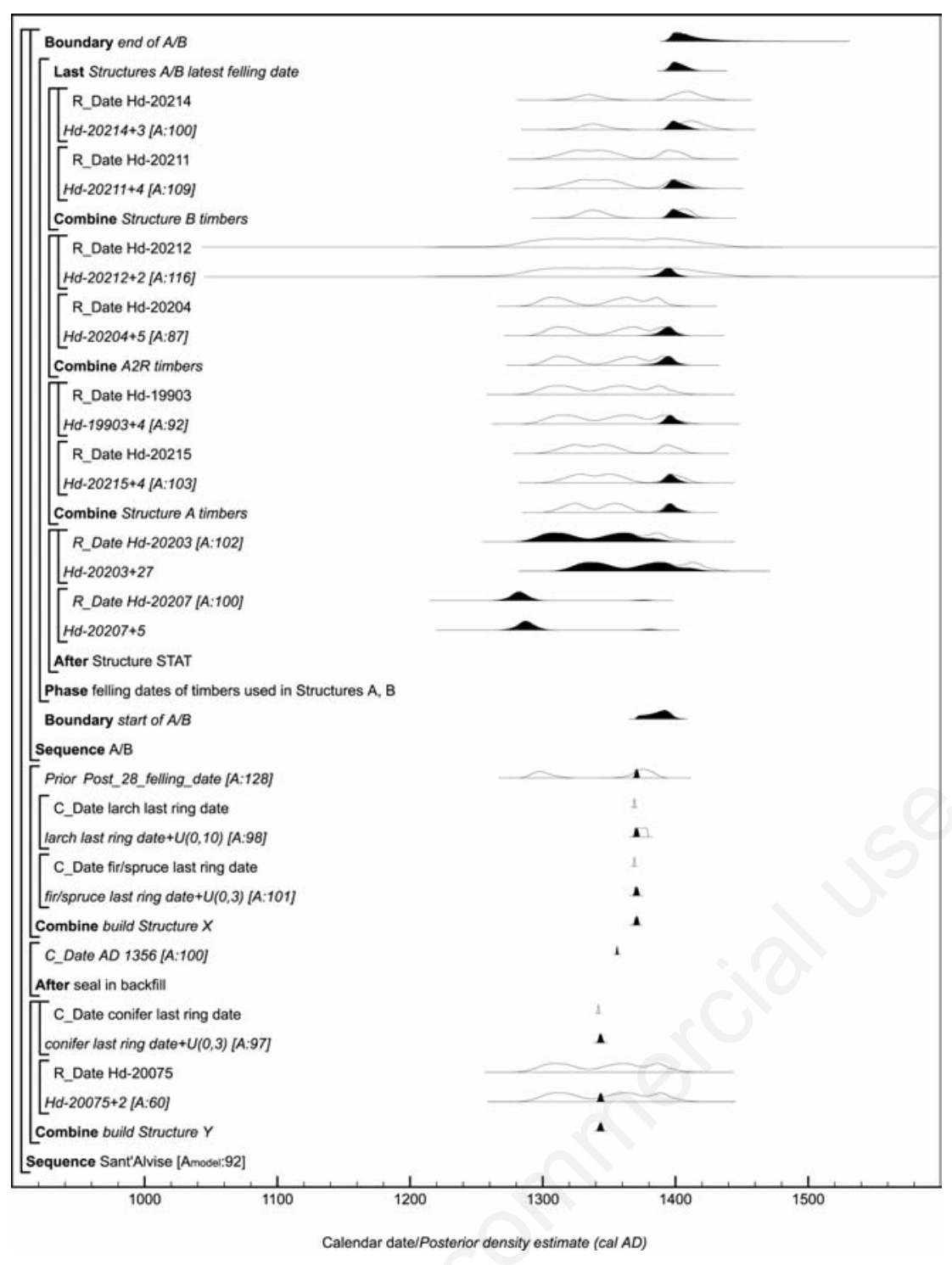

Figure 3. The Bayesian model, implemented in OxCal 4.1.7 (Bronk Ramsey, 2009), with the earliest event at the bottom of the diagram. The model structure is exactly defined by the brackets and OxCal keywords in bold type. Solid distributions are the model's posterior density estimates of the dates of samples and events; distributions in outline are historical dates or dendrochronological felling date ranges (C_Date), or calibrated radiocarbon results (R_Date), or the likelihood for the felling date of Post 28, calculated below (Prior). Each calibrated date has been offset by half the number of annual rings in the radiocarbon sample to obtain a more precise felling date distribution, which is used as a likelihood in the model.

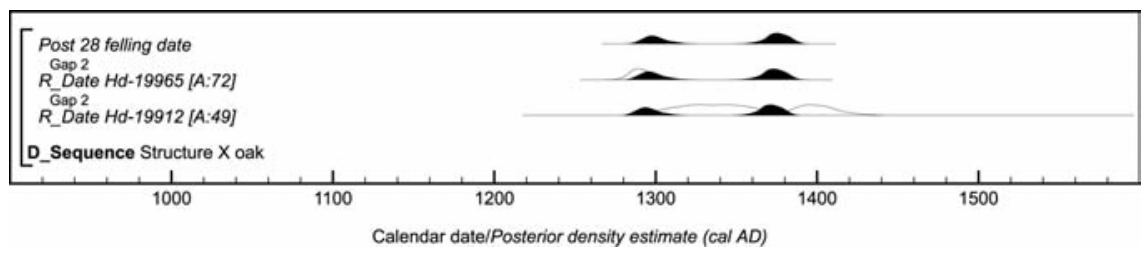

Figure 4. Wiggle-matching of Posts 14 and 28, Structure X. Distributions in outline are calibrated radiocarbon results (calibration by the probability method) (Stuiver and Reimer, 1993), using the IntCal09 data set. Solid distributions are the model's posterior density estimates of the dates of these samples and of the felling date of Post 28.
Structures A and B can be dated rests on the Bayesian model, and we can vary the model to investigate the significance of its components.

A version of the Figure 3 model in which cross-matching between Structure A/B samples is ignored gives a similar posterior density estimate for the last felling date (cal $A D$ 1392-1418, 95\% probability). An oak-only model, which uses the stratigraphic sequence and cross-matches between radiocarbon samples, but not the artifact date or conifer dendrochronology, dates the last felling to $\mathrm{cal} A D$ 1386-1426 at $88 \%$ probability. If the crossmatches are also ignored (i.e. a radiocarbononly model), the same event is dated to $\mathrm{cal} A D$ 1391-1424 at $94 \%$ probability. A model that uses oak and conifer dendrochronology and the artifactual date, but which does not specify that Structures $\mathrm{A} / \mathrm{B}$ are later than Structure $\mathrm{X}$, dates the last felling in Structures $\mathrm{A} / \mathrm{B}$ to $\mathrm{cal}$ AD 1328-1377 or $1384-1417$ (42 and 54\% probability respectively).

Thus cross-matching between radiocarbon samples is less significant here than the precise termini post quos given by conifer dendrochronology and an artifact, and is certainly less significant than the stratigraphic sequence. This is unsurprising, as crossmatches are only available for samples which are too similar in date for cross-matching to indicate which peak of a multi-modal probability distribution is relevant, whereas the sequence of structures spanning 50-80 years serves precisely this purpose. Cross-matching also reduces the number of likelihoods (independent estimates of felling dates), which may limit the effect of OxCal's Boundary function (Bronk Ramsey, 2000) in constraining the scatter in a set of radiocarbon dates. As crossmatching shows that the dates of some samples are not independent, however, ignoring cross-matches may give unrealistically precise posterior density estimates.

\section{Conclusions}

Land reclamation in Sant'Alvise began with the construction of Structure Y in the early $\mathrm{AD}$ 1340s. In the early AD 1370s, Structure X was built, and the reclaimed area was extended by the construction of Structures A and B, probably within a decade of cal AD 1400 . Artifactual assemblages from the deliberate backfill of each structure must predate its construction, but finds from layers which accumulated after each structure was built were deposited over the course of 2 or 3 decades in the mid-14 century $\mathrm{AD}$ (between Structures $\mathrm{Y}$ and $\mathrm{X}$ ) and the late $14^{\text {th }}$ century $\mathrm{AD}$ (between Structures $\mathrm{X}$ and $\mathrm{A} / \mathrm{B})$. The date ranges obtained from Bayesian modeling will serve as useful 
absolute chronological markers for the rich pottery assemblage found at the site, notably that recovered from the landfill layers associated with Structures $\mathrm{Y}$ and $\mathrm{X}$, which, in addition to Venetian productions, also includes imports, such as luster-decorated ware from Spain, Syro-Egyptian fritwares and, to a lesser extent, glazed ceramics from southern Italy (Anglani et al., 2012). The Bayesian modeling exercise has demonstrated the importance of incorporating all available dating evidence in a single model.

\section{References}

Anglani L, Martinelli N, Pignatelli 0, 2012. [Materiali ceramici dalle arginature tardomedievali di S. Alvise, Venezia. I dati relativi alle strutture lignee più antiche del sito datate tramite la dendrocronologia e il radiocarbonio]. In: [Atti del IX Congresso Internazionale sulla Ceramica Medievale nel Mediterraneo (AIECM2), 2009 Nov 23 29, Venice, Italy]. [Proc. in Italian]. All'Insegna del Giglio ed., Florence, pp. 388-394.

Aniol RW, 1983. Tree-ring analysis using CATRAS. Dendrochronologia 1:45-53.

Baillie MGL, 1982. Tree-ring dating and archaeology. Croom Helm, London and Canberra.

Bebber AE, 1990. [Una cronologia del larice (Larix decidua Mill.) delle Alpi orientali italiane]. [Article in Italian]. Dendrochronologia 8:119-39.

Bebber AE, Burro M, Martinelli N, Pignatelli 0, Stroppa M, 1992. Coniferous tree-ring chronologies for Northern Italy. Lundqua Report 34:14-6.

Becker B, Billamboz A, Egger H, Gassmann P, Orcel A, Orcel C, Ruoff U, 1985. [Dendrochronologie in der Ur- und Frühgeschichte: die absolute Datierung von Pfahlbausiedlungen nördlich der Alpen im Jahrringkalender Mitteleuropas]. [Book in German]. Verlag Schweizerische Gesellschaft für Ur- und Frühgeschichte, Basel.

Billamboz A, 1989. [Archéologie du bois et analyse des cernes]. In: J.P. Mohen (ed.) [Le temps de la Préhistoire. Vol. I]. [Book in French]. Société Préhistorique Française ed., Paris, pp. 220-5.

Bortoletto M, 2005. [Archeologia e edilizia sulle rive del Canal Grande tra XII e XV secolo]. In: L. Fozzati (ed.) [Ca'
Vendramin Calergi. Archeologia urbana lungo il Canal Grande di Venezia]. [Book in Italian]. Marsilio ed., Venice, pp. 23-37.

Bronk Ramsey C, 1995. Radiocarbon calibration and analysis of stratigraphy: the OxCal program. Radiocarbon 37:425-30.

Bronk Ramsey C, 2000. Comment on 'The use of Bayesian statistics for $14 \mathrm{C}$ dates of chronologically ordered samples: a critical analysis'. Radiocarbon 42:199-202.

Bronk Ramsey C, 2009. Bayesian analysis of radiocarbon dates. Radiocarbon 51:337-60.

Bronk Ramsey C, van der Plicht J, Weninger B, 2001. 'Wiggle matching' radiocarbon dates. Radiocarbon 43:381-9.

Buck CE, Cavanagh WG, Litton CD, 1996. Bayesian approach to interpreting archaeological data. Wiley, Chichester.

Cambini A, 1967. [Riconoscimento microscopico del legno delle querce italiane]. In: CNR-Istituto Nazionale del Legno (ed.) [Contributi scientifico-pratici per una migliore conoscenza ed utilizzazione del legno, Vol. X]. [Book in Italian]. CNRIstituto Nazionale del Legno ed., Florence, pp. 53-69.

Concina E, 2000. [Venezia, tra due elementi sospesa]. In: L. Anglani (ed.) [Tra due elementi sospesa. Venezia, costruzione di un paesaggio urbano]. [Book in Italian]. Marsilio ed., Venice, pp. 15-51.

Concina E, 2003. [In description con pentura. Note sulla rappresentazione urbana e sulla cartografia nella Venezia del Trecento]. In: F. Borin, F. Pedrocco (eds.) [Venezia e Venezie. Descrizioni, interpretazioni, immagini. Studi in onore di Massimo Gemin]. [Book in Italian]. Il Poligrafo ed., Padua, po. 15-21.

Corona E, 1970. [Cerchie dell'alburno in tronchi di rovere]. [Article in Italian]. L'Italia Forestale e Montana 25:156-8.

Corona E, 1974. [Ricostruzione dell'alburno in legnami sommersi]. [Article in Italian]. Geoarcheologia 1/2:19-22.

Corona P, 1984. [Anelli d'alburno in larice cisalpino]. [Article in Italian]. Dendrochronologia 2:91-7.

Fozzati L, 1997. [S. Alvise di Cannaregio - area ex-CIGA: l'evoluzione di un tratto del margine lagunare urbano dall'inizio del Trecento al tardo Cinquecento. Nota preliminare]. [Article in Italian]. Quaderni di Archeologia del Veneto 13:146-54.

Friedrich M, Remmele S, Kromer B, Hofmann J, Spurk M, Kaiser KF, 2004. The 12,460year Hohenheim oak and pine tree-ring chronology from central Europe - a unique annual record for radiocarbon calibration and paleoenvironment reconstructions. Radiocarbon 46:1111-22.

Fritts HC, 1976. Tree rings and climate. Academic Press, London.

Kromer B, Münnich KO, 1992. CO2 gas proportional counting in radiocarbon dating review and perspective. In: R.E. Taylor, A. Long, R.S. Kra (eds.) Radiocarbon after four decades: an interdisciplinary perspective. Springer, New York, pp. 184-97.

Lambert GN, Orcel C, 1977. [L'état de la dendrochronologie en Europe occidentale et les rapports entre dendrochronologie et archéologie en Suisse].[Article in French]. Arch Suisses Anthropol Gen 41:73-97.

Levanič T, Pignatelli 0, Čufar K, 2001. A regional larch chronology of trees and historical buildings from Slovenia and Northern Italy. Dendrochronologia 19:2219.

Reimer PJ, Baillie MGL, Bard E, Bayliss A, Beck JW, Blackwell PG, 2009. IntCal09 and Marine09 radiocarbon age calibration curves, $0-50,000$ years cal BP. Radiocarbon 51:1111-50.

Rinn F, 2003. TSAP-Win ${ }^{\mathrm{TM}}$. Time series analysis and presentation for dendrochronology and related applications. Version 0.59 for Microsoft Windows 98, 2000, XP. User reference. Rinntech ed., Heidelberg.

Schweingruber FH, 1990. [Anatomie europäischer Hölzer. Ein Atlas zur Bestimmung europäischer Baum-, Strauch- und Zwergstrauchhölzer/Anatomy of European woods. An atlas for the identification of European trees, shrubs and dwarf shrubs]. [Book in German/English]. Haupt, Bern and Stuttgart.

Stuiver M, Polach HA, 1977. Discussion: reporting of 14C data. Radiocarbon 19:35563.

Stuiver M, Reimer PJ, 1986. A computer program for radiocarbon age calculation. Radiocarbon 28:1022-30.

Stuiver M, Reimer PJ, 1993. Extended 14C data base and revised CALIB $3.014 \mathrm{C}$ age calibration program. Radiocarbon 35:215-30.

Stuiver M, Reimer PJ, Bard E, Beck JW, Burr GS, Hughen KA, 1998. IntCal98 radiocarbon age calibration, 24,000-0 cal BP. Radiocarbon 40:1041-83.

Ward GK, Wilson SR, 1978. Procedures for comparing and combining radiocarbon age determinations: a critique. Archaeometry 20:19-31. 